\title{
AN ECONOMIC OVERVIEW OF OTTOMAN STATE RECORD OF TAXES: TEMETTUAT (PROFIT TAX) REGISTERS OF NIĞDE SANJAK (1844-1845)
}

\section{Ali Gökhan GÖLÇEK* - Altuğ Murat KÖKTAŞ**}

\author{
Öz \\ Osmanlı Devleti Vergi Kayıtları Üzerine Ekonomik Bir Bakış: \\ Niğde Sancağı Temettüat Tahrirleri (1844-1845)
}

Osmanlı Devleti'nde gerileme dönemi sonrası görülen yönetimsel ve mali bunalımların etkilerinin silinmesini amacıyla, 1839 yılında Tanzimat Fermanı ilan edilmiş ve ferman ile bazı reform uygulamaları da hayat bulmuştur. $\mathrm{Bu}$ anlamda devletin vergileme sistemi değiştirilerek, mali bunalımdan çıkması amaçlanmıştır. Tanzimat sonrası tutulmaya başlanan Temettüat Tahrirleri, mikro ölçekte bölgelerdeki hane-halkının sosyoekonomik durumuna ilişkin ayrıntılı bilgiler veren; emlak, arazi, hayvanat ve temettü üzerinden alınan vergilerin tek bir defterde tutulmasını sağlayan kayıtlardır. Çalışmanın konusunu Karaman Eyaleti, Niğde Sancağına bağlı Kalkanlı Kazası Bâzirgân Karyesi ile Anduğu Kazasına bağlı Ortaköy Karyesinin temettüat defterlerinde yer alan bilgiler ışı̆̆ında, söz konusu kazalardaki gelir dağılımı ve göreli yoksulluk oluşturmaktadır. Yapılan hesaplamalar neticesinde ilgili kazalarda, Gini Katsayısı 0.3477 ve göreli yoksulluk oranı ise $\% 24$ çıkmıştır. Bu bağlamda vergi uygulamalarının, gelir dağılımda eşitsizliği tetiklediği ve regresif sonuçlar verdiği tespit edilmiştir.

Anahtar Kelimeler: Temettüat Tahrirleri, Niğde Sancă̆ı, Göreli Yoksulluk, Gelir Dă̆ılımı.

\begin{abstract}
In 1839, the Imperial Edict of Gülhane was declared to erase the impacts of the administrative and financial crises following the Ottoman Regression period. In this sense, the taxation system of the state was changed and it was aimed to overcome the financial crisis. Temettüat (profits tax) registers started to be kept after the Imperial Edict of Gülhane are the records that keep the taxes on micro-scale of the socioeconomic status of the households in the region provides detailed
\end{abstract}

\footnotetext{
* Research Assistant, Niğde Ömer Halisdemir University, Faculty of Economics and Administrative Science, Niğde. E-mail: aligokhangolcek@gmail.com, ORCID: 0000-0002-7948-7688

** Assoc. Prof., Necmettin Erbakan University, Faculty of Political Science, Konya. E-mail: altugmkoktas@gmail.com, ORCID: 0000-0002-0911-2143

(Makale Gönderim Tarihi: 29.04.2019 - Makale Kabul Tarihi: 09.12.2019)
} 
information; real estate, land, zoological and profit in a single book record. The subject of the study consists of the income distribution and relative poverty in the light of the information in the dividend books of Kalkanlı District, Bâzirgân Karyesi and Ortaköy Karyesi of Anduğ District that were connected to Niğde Sanjak, Karaman Province. As a result of the calculations, Gini Coefficient was 0.3477 and relative poverty rate was $24 \%$ in these districts. In this context, taxation practices are found to be triggering income distribution inequality and yielding regressive consequences.

Key Words: Temettuat (Profit tax) registers, relative poverty, income distribution.

\section{Introduction}

The study aims to examine the results of the regulatory reforms in Niğde Sanjak of Karaman province and to determine the extent to which the Ottoman Empire succeeded in the financial crises that first noticed in the $16^{\text {th }}$ century ${ }^{1}$. As a reformist movement after the Imperial Edict of Gülhane; a population census was taken by the Ministry of Finance between 1844 and 1845, only for once. As a result of the population census taken, the annual income of the people in that region, the tax that they paid, agricultural products and livestock were identified. The population census was recorded in the books called Temettuat Tahrirleri (Temettuat -Profit Tax- Registers). Besides socioeconomic implications on the region studied in micro-scale by means of these books, the extent to which the system worked efficiently throughout the whole empire at macro-scale was rendered measurable. Although the Ottoman Empire survived many political and financial crises throughout its entire lifespan of six centuries, the industrialization of Europe by spreading new economic systems had changed and deepened the crisis experience. Besides external cyclical movements, the system failure that had been functioning in the country made the financial depression became a chronic disease regarding the Ottoman State. Despite all efforts and struggles in seeking a way out of the depression via reform movements, the Ottoman State became an economic market for foreign countries.

The main topic of the study is comprised of the socioeconomic status of two separate villages regarding Temettuat (Profit Tax) Registers of Niğde Sanjak. In this context, the importance of temettuat registers is mentioned, and the information about the socioeconomic status of those villages is examined. The obtained findings within the scope of temettüat registers on real estate, land, livestock, and dividend are presented, and the Gini coefficients of Bâzirgan and Ortakoy villages of Niğde Sanjak are calculated. In this context, information on how the revenues were distributed and the relative poverty rate is mentioned the last part of the study. Consequently, it is examined how far tax reform following the Imperial Edict of Gülhane could have been applicable and

\footnotetext{
${ }^{1}$ For the financial crisis of the Ottoman State, please see: Sakal and Gölçek 2017.
} 
An Economic Overview of Ottoman State Record of Taxes: Temettuat (Profit Tax)

Registers of Niğde Sanjak (1844-1845)

the tax rates are found not to be determined fairly among the households. Evaluations are made in the light of archival documents and auxiliary sources within this study that examines the results of the tax reform carried out by the Ottoman State in particular for Niğde Sanjak.

\section{Niğde Sanjak in the Ottoman Empire}

Niğde, located at an altitude of 1,190 meters above sea level in the southern part of the Melendiz Mountains, had been ruled by the Karamanogullari Principality following the collapse of the Anatolian Seljuk State $^{2}$. Following the foundation of the Ottoman Empire, Niğde joined the Ottoman lands in 1397 after Yildirim Bayezid defeated the Karamanids Principality at the Battle of Akcay. However, after a while, the Anatolian unity was destroyed along with the Battle of Ankara which took place in 1402, and Niğde was left to the Karamanids Principality once again ${ }^{3}$.

In the following years, with the help of the unity in Anatolia, Niğde became a sanjak of Karaman Province under the reign of the Ottoman Empire in 1470. The first information related to the administrative structure of Niğde Sanjak was placed in the population census documents dated 1576. According to these documents, there were two counties in the sanjak, namely the Central Niğde and Urgup. Later on, Karahisar-i Develi, as one of the neighbours of Urgup county, was accepted as the third county. There were twenty-nine neighbourhoods and 731 households in Niğde according to the population census records of the $16^{\text {th }}$ century. While 674 of these were Muslim; fifty-seven were non-Muslim. Niğde had a population of approximately 4,000-5,000 residents in that century ${ }^{4}$. Throughout the $16^{\text {th }}$ century, the population of Niğde Sanjak had been gradually increasing ${ }^{5}$.

The first population census was carried out in 1831 except for avartz tax registers in the Ottoman Empire. However, the population census of 1831 does not contain very reliable outcomes ${ }^{6}$. Because the census had been made only on the males who were taxpayers and women-children and non-Muslims (reaya) were not included. According to this census, there were 3,353 Muslims and 14,703 non-Muslim subjects in the city of Niğde. It is not clear to whom exactly the concept of reaya is met in the census. However, it was determined that there

\footnotetext{
${ }^{2}$ Oflaz 2007, 33, 93; Selçuk 2013, p. 1264.

${ }^{3}$ Oflaz 2007, p. 93; Öztuna 1997, p. 306; Uzunçarş11 1995, pp. 309-310.

${ }^{4}$ Oflaz 2007, p. 93.

${ }^{5}$ Metin 2016, p. 37.

${ }^{6}$ Akbal 1951, pp. 618-619; Karpat 2003, p. 38.
} 
be 895 residents in villages and 41,025 residents in the sanjak. Therefore, the total number of male taxpayers in Niğde Sanjak was recorded as 60,176. Aksaray county was not included in these figures, and it was considered as a sanjak at the population censuses ${ }^{7}$.

Niğde, which appeared as affiliated to Konya Province in 1840, was included to the Liva of Nevsehir with the administrative arrangement made in 1847. Niğde acquired the status of sanjak again in 1849, and it was comprised of six counties by the year 1887. Those counties were the Central Niğde, Nevsehir, Urgup, Aksaray, Bor and Hamidiye/Ulukisla. According to Konya Province Almanac (Salname) dated 1900, Arabsun (Gulsehir) and Maden (Camardi) counties were added to Niğde Sanjak in 1903. Niğde, which acquired the status of an independent sanjak during the II. Constitutional Monarchy, became a province in the Republican period ${ }^{8}$.

The majority of the residents that lived in the central county of Niğde Sanjak were administrators, tradesmen, and craftsmen ${ }^{9}$. Rug weaving, carpentry, and coppersmith were some of the crafts that existed in the city. In the villages, agriculture and livestock were heavily exercised, and most of the population was farmers.

In Bor, as one of the important counties of Niğde, had 35 thousand hectares of agricultural land and about half of this land was planted, and crops such as wheat, barley, rye were grown in Niğde Sanjak ${ }^{10}$. Nevertheless, the fact that it was not located on trade routes had caused the underdevelopment of trade in the city ${ }^{11}$.

Mining, which is an important area for both monetary system and defence industry in the Ottoman Empire, also occupied an important place in Niğde Sanjak. Especially the presence of silver and saltpeter mines in the region was crucial to the operation of these mines both economically and as a contribution to the defence industry. In particular, along with the use of saltpeter as raw material for gunpowder, heavy industrial movements in military terms had started in Niğde Sanjak ${ }^{12}$.

The most important saltpeter producing region of Anatolia where 13 (thirteen) production facilities existed was Karaman Province as of the second

\footnotetext{
${ }^{7}$ Kaya 2006, p. 197.

${ }^{8}$ Oflaz 2007, p. 95.

${ }^{9}$ Akşit 2009, p. 26.

${ }^{10}$ Galanti 1951, pp. 68-69.

11 Aktüre 1975, p. 15.

12 Tabakoğlu 2014, p. 341.
} 
half of the $16^{\text {th }}$ century. In the following years, the saltpeter had been extensively produced in Aksehir, Icil, Konya, Niğde, Aksaray, Kayseri, and Kirsehir sanjaks as well as places such as Kilisehisar, Develi, Larende, Sarkisla, Sarimsak, Bozok, Cirlavuk, Kemerhisar, Kochisar, Budak Ozu and Urgup. Furthermore, the most important gunpowder production center was located in Bor county of Karaman Province ${ }^{13}$. In this context, it is seen that the Niğde-Bor region was an important place in meeting the needs of the Ottoman army ${ }^{14}$.

\section{Temettuat (Profit Tax) Registers: 1844-1845}

Temettuat Registers had the quality of basic sources that indicate the economic and social history of the $19^{\text {th }}$ century Ottoman Empire including the layout for the settlement of the population living in the Empire, the wealth of the households, the agricultural activities and the amount of the taxes paid most comprehensively. However, there were some points at which Temettuat Registers were insufficient. For instance, since these records were only kept on a specific date, they allow stationary analyses. Because no censuses were held neither at the beginning nor the end of the $19^{\text {th }}$ century. Another issue on which they were inadequate was that not all the elements of the people's wealth were included to the census. Indeed, only income-yielding wealth such as vineyards, orchards, and farming lands as well as rent-yielding estates such as inns, bathhouses, shops, grinding mills, and livestock were subjected to the census. Whereas the houses in which one lived, the shops where tradesmen and merchants had performed their occupation, the money, debts, possessions, tools and merchandise stocks were excluded from the census. In addition to these inadequacies, Temettuat Registers have given healthy results in terms of income distribution. Rich, poor and middleincome households in the examined region/province and tax burdens, pre-tax and after-tax income of those households can be evaluated ${ }^{15}$.

The new taxation method which aims to levy an annual tax of $3 \%$ on income resembles a declaration- based tax system. This method, in which the taxpayers do not declare their incomes that are registered by the government officials in the related books, takes all kinds of agricultural activities and real estate elements that would be obtained along with the specific characteristics of a household into consideration. Therefore, the application of a "declaration-based income" is introduced ${ }^{16}$. Accordingly, name/nickname, amount of property, land,

\footnotetext{
${ }^{13}$ Agoston 2006, pp. 138-191.

${ }^{14}$ Güven 2004, p. 403.

${ }^{15}$ Güran 2014, pp. 198-202.

${ }^{16}$ Şener 2007, p. 118.
} 
livestock and an annual income of everyone in every neighborhood would be estimated without exception. In this context, “not a single penny's worth of tax would be levied by determining to what extent everyone is obligated to pay taxes in one year" ${ }^{\prime 17}$.

Temettuat Registers are haused in the Ottoman Archives of the Prime Minister's Office. The archive comprises over 17,000 notebooks. Most of the books date back to the period between 1260-1261 (1844-1845). Those belong to Ankara, Aydin, Bolu, Cezayir-i Bahr-i Sefid, Edirne, Erzurum, Hudavendigar, Konya, Nis, Rumeli, Thessaloniki, Silistre, Sivas, Skopje, Vidin and various other regions ${ }^{18}$.

The main features of the tax in the notebooks are basically under the household registry name records. The names were often written in the form of "oglu", "bin" or "veled." In some records, such qualities as medium-sized, black-bearded or pilgrim (haci) and chief (aga) were found. Secondly, the occupations of household heads were recorded. According to this, the notebooks include such occupations as farmer, blacksmith, merchant, tanner, miller, tinsmith, sipahi, imam, tailor, painter, shepherd and grocer. Those without regular income (or with no income at all) were commonly referred to as basibos, mecnun, duskun, divane, hatun or muhtac. Besides presenting the general characteristics of the household head, temettuat registers appear to record the land, livestock and real estate under their possession in detail. Accordingly, once the acreage or the number of vineyards, orchards, allotments and similar real estate were calculated, the annual obtained revenues were estimated. The notebooks in which the cultivated fields were recorded as "mezru tarla" also indicated the fields that were rented or left empty. Nonetheless, the number of crops produced by of the household heads was written down in detail due to the tithe tax to be paid. In Temettuat Registers, the livestock are placed after the real estate. In this context, it is easy to determine which and how many livestock were to be raised in the area where the notebook belonged. Various characteristics of the livestock, if any, were also featured. For instance, qualifications such as milch cow, female cow, inseminated cow, male water buffalo, milch goat and barren goat were encountered in Niğde Province's notebooks. Later, the annual revenue from the livestock was shown separately.

Another title that is seen in Temettuat Registers is the taxes. According to this, following the household information, "meslek" (profession), "vergi-i mahsusa" (special tax), "öşür” (tithe) are written down vertically respectively.

\footnotetext{
${ }^{17}$ Kaynar 1991, p. 241.

${ }^{18}$ Başbakanlık Osmanlı Arşivi Rehberi (Ed. İ. Genç and others.), İstanbul 2010, p. 248.
} 
An Economic Overview of Ottoman State Record of Taxes: Temettuat (Profit Tax)

Registers of Niğde Sanjak (1844-1845)

The amount of tax paid is reported to be "collected in the previous year." Tithe tax, as another financial obligation that was reported to be "collected in the previous year," indicates the values levied on such elements as wheat and barley.

\section{Data and Methodology}

Temettuat Registers that consist of real estate, land, livestock, and dividends are placed in the Financial Revenues catalogues (BOA, ML, VRD, TMT.d) of Ottoman Archives of the Prime Ministry's Office. Totally 17,747 notebooks pertaining to the years 1256-1261 (1840-1845) are present the nine catalogues, and it is estimated that approximately 1.1 million households were included in the temettuat censuses. Nonetheless, some of the books are classified as in Kamil Kepeci and Maliye Mudevver Notebooks ${ }^{19}$.

The subject of the work is the Temettuat Registers of Kalkanli County, Bâzirgân Village of Niğde Sanjak located within Karaman Province and Ortakoy Village within Andugu County. Temettuat Registers of Bâzirgân Village consists of 36 pages, 17x49 in size, without marbling and binding cover. This notebook is logged at the Financial Revenues catalogue with BOA. ML. VRD. TMT.d.10558 sequence number in the Ottoman Archives of the Prime Minister's Office. The last two pages are empty, and there are 94 households in this book. The notebook of Ortakoy Village within Andugu County is comprised totally 20 pages, 21x58 in size, without marbling and binding cover. There exist 38 households recorded in this notebook which is logged at the Financial Revenues catalogue with BOA. ML. VRD. TMT. d.15982 sequence number in the Ottoman Archives of the Prime Minister's Office. In this context, the study covers a total of 132 households in both regions. The 1260-1261 (1844-1845) temettuat registers belonging to both settlements were obtained from the Ottoman Archives of the Prime Minister's Office and were translated into contemporary Turkish. These two notebooks, which have not been subject to scientific research before and have not been translated in this context, constitute the original aspect of the study.

The data obtained from the notebooks indicate names, occupations, annual incomes, real estate, lands, livestock of the households as well as financial obligations they were subject. The financial obligations to be paid, besides an-cema'tinatin (commodity tax), levied as dividend tax, were aşar, rusumat and adet-i agnam.

\footnotetext{
${ }^{19}$ Güran 2000, pp. 76-79.
} 
Table 1. Descriptive Statistics

\begin{tabular}{|lccccc|}
\hline & Observation & Mean & $\begin{array}{c}\text { Stand. } \\
\text { Dev. }\end{array}$ & Min. & Max. \\
\hline Household & 132 & 66.5 & 38.24918 & 1 & 132 \\
\hline Income & 132 & 1160.78 & 711.5369 & 0 & 3.100 \\
\hline Vergi-i Mahsusa (Special Tax) & 132 & 154.0265 & 121.0215 & 0 & 720 \\
\hline $\begin{array}{l}\text { Aşar ve Rusumat (Tithe Tax and } \\
\text { Duty Charges) }\end{array}$ & 132 & 49.25758 & 36.13277 & 0 & 148 \\
\hline $\begin{array}{l}\text { Adet-i Agnam (Small Ruminant } \\
\text { Tax) }\end{array}$ & 132 & 0.5530303 & 1.542351 & 0 & 12 \\
\hline
\end{tabular}

The descriptive statistics obtained from temettuat registers are shown in Table 1. Accordingly, incomes of totally 132 households recorded in the notebook were classified as agricultural and non-agricultural. It is determined that the average income per household was 1,160,78 kurus while the lowest income was 0 and the highest income was 3,100 kurus. There were totally five households with no income in the record books. The first one of these was Hasan, the son of Yusuf who resides in Ortakoy Village and was registered with household number 29 in the notebook. It is found that the following entries were made for that individual: "Aforementioned individual has no real estate and land other than his households so that he subsists on alms from others" and "Aforementioned individual is old and ill, the tithe and commodity tax payment he made in the last year: 0 kurus". The second household was Ibrahim, the son of Seyf, who lived in the same place with household number 34. Since he had no income at all, it is written that he had not made any tax payments and "he owned nothing other than his house." The third person with no income was Mecnûn Osman, who had been living in the same place with household number 38. The following entry states that this individual had no income: "Aforementioned individual has no object except for his house." The fourth individual without any income was Sabi Halil, the son of Yunus Sipahî who was residing in Bâzirgân Village with household number 51. The following entry indicates that this person had no income since he was just a child: "Aforementioned infant has no real estate or land." The fifth and last person was Calik Mehmed, who also lived in Bâzirgân Village with household number 93. After specifying the absence of any taxes paid within a year, the following entry was recorded: "Aforementioned individual has no property, real estate or land and he subsists on alms from others." In this context, it is determined that there be no financial obligations of five persons due to the absence of any income. 
It is determined that the commodity tax (an-cema'tin) levy as dividend tax, which was brought in parallel with the changing taxation mentality of the Imperial Edict of Gülhane, was not paid by five households in total. Nonetheless, despite having a certain level of income from the agricultural activity, it is determined that two households did not have a tax record and one household was exempted due to the service of muhtar (village headman).

It can be considered that there had been an error in the household records. On the other hand, similar errors are detected in records and simple mathematical mistakes such as addition are corrected. For instance, the income items of the richest households mentioned above were listed as 1,560 kurus for agricultural activity and 1,540 kurus for extraordinary items. Considering the household average of taxes, it is seen that approximately 154 kurus worth of tax per household had been paid. The highest amount of tax payment belonged to the individual named Sari Huseyin who resided in Bâzirgân Village with household number 75. It is noteworthy that this household, which engaged in agricultural activities, had incurred the highest taxpayer's payment in accordance with the new taxation levied on income although it did not earn the highest amount of income. This brings to mind the problems experienced by the tax collectors similar to the previous applications.

In the case of tithe and duty charge payments, which were other financial obligation, the average payment was approximately 50 kurus per household. It is determined that the highest amount of payment was 148 kurus and that it was made by Mehmed Efendi, the son of Hasan Efendi who resided in Bâzirgân Village household number 58, and Osman, the son of Hâfiz with household's number 69. Similarly, it can be considered that the calculation of these financial obligations would also be a problem when the income from agricultural activities of the both households was estimated to be 2,435 kurus and 2,050 kurus, respectively. On the other hand, except for the muhtars, it is discovered that 11 households had not made any tithe or duty charge payments, even though they had earned income from the agricultural activities.

\section{Findings}

There are 94 households in the temettuat registers of Bâzirgân Village, and 38 households in the notebooks of Ortakoy Village within Andugu County. The scope of the study in this context is comprised of totally 132 households located in both regions. Given the general characteristics of the households, it is seen that the vast majority of them had maintained their subsistence through agricultural activities. According to this, 91\% of the households were farmers. 
The rest of the households were as follows: three worker households, one soldier household, one muhtar household, two divane (insane) households and one elderly household. The professions and the sources of subsistence for other two households were not mentioned. The divane, the elderly, and the soldier households had not been found to have any financial obligation to pay since no income had been recorded for them.

Table 2. Distribution of the Households According to Profession Groups (unit)

\begin{tabular}{|lcccccc|}
\hline & Farmer & Worker & Soldier & Divane & Muhtar & Others \\
\hline Household & 120 & 3 & 1 & 1 & 1 & 6 \\
\hline
\end{tabular}

The average agricultural income per household is calculated as approximately 605 kurus upon the examination made on the agricultural activity incomes earned by the households. 53\% of the households had their agricultural earnings below the average. The household with the highest income of 1,935 kurus from agricultural activities belonged to Mehmed Efendi, the son of Hasan Efendi, who had been residing in Bâzirgân Village with household number 58. In total, there were six households with no agricultural earnings. However, even though it was written as a farmer in the notebook records, one household is detected to have no agricultural or any other income. In the notebooks, the obtained agricultural earnings were recorded with the expression such as "of agriculture experts."

If the household head had any income other than that, they are also referred to such definitions as "Zuhûrât temettu'âtı (Contingency Earnings)" (Household number 35), "Kereste ve hatab kat 'indan zuhûrât temettu'âtı (Contingency Earnings from Lumber and Wood)" (Household number 94), "Kereste naklinden zuhûrât temettu'âtı (Contingency Earnings from Lumber Transportation)" (Household number 39) and "Destbânlıktan ve zuhûrât temettu 'âtı (Contingency Earnings from Protection of the Cultivated Lands)" (Household number 47).

The average income per household is determined as 1,160 kurus with the inclusion of other incomes. In this case, it is seen that 53\% of the households had incomes below this amount. The richest household living in the region (a total income of 3,100 kurus) belonged to Hasan, the son of Deli Ali, who resided in Bâzirgân Village with household number 62. As mentioned earlier, the five households did not have any income, neither agricultural nor other. Another issue that attracts attention in notebooks is that all three workers were not placed at the end of income distribution. For example, Ali, the son of Biyikli who lived in Bâzirgân Village with household number 20 had a total income of 
An Economic Overview of Ottoman State Record of Taxes: Temettuat (Profit Tax) Registers of Niğde Sanjak (1844-1845)

675 kurus obtained from lumber transportation (600 kurus) and livestock (75 kurus). The income distribution according to the $20 \%$ quintiles calculated by considering the total incomes of the households are shown in Table 3.

Table 3. The Share of Income of the Population in Andugu ve Kalkanli Counties concerning 20\% Quintiles (\%)

\begin{tabular}{|lcc|}
\hline Income Quintiles & $\begin{array}{c}\text { The Share of Income } \\
\mathbf{( \% )}\end{array}$ & $\begin{array}{c}\text { Cumulative Total } \\
\text { (\%) }\end{array}$ \\
\hline The First 20\% Quintile & 4.3 & 4.3 \\
\hline The Second 20\% Quintile & 11.7 & 16 \\
\hline The Third 20\% Quintile & 20 & 36 \\
\hline The Forth 20\% Quintile & 27 & 63 \\
\hline The Fifth 20\% Quintile & 37 & 100 \\
\hline
\end{tabular}

As a result of calculating the total amount of the incomes obtained by the households, the table indicates the distribution of incomes by $20 \%$ quintiles, so that the households in the first poorest quintile could have only taken $4.3 \%$ of total income. In this quintile where 27 households were located, the average total income per household is calculated as 248.48 kurus. In this context, the income levels of aforementioned households were below the previously calculated average income per household. Nine of the households consisted of divane, soldiers, elders and workers mentioned earlier, while the others were farmers. The fifth poorest households had no income and no financial obligation to pay. The households of the second $20 \%$ quintile had $11.7 \%$ of the total income. In this quintile in which totally 26 households were located, the average income per household was 683 kurus. Therefore, the income level of the households in the second quintile was also below the average income level. Household heads in this quintile were farmers, except for a muhtar and a worker. The richest household of the second quintile belonged to Osman, the son of Yerik Ahmed who lived in Bâzirgân Village with household number 36. The households of the third $20 \%$ quintile seem to have received $20 \%$ of the total income. The households in the third quintile of the income distribution were all farmers and the average income per household was 1,127 kurus. However, all of the households in this quintile had extraordinary income items besides agriculture. Haci Yusuf, the son of Mustafa who lived in Bâzirgân Village with household number 52, was the richest individual of this quintile along with a total income of 1,415 kurus. It is determined that the fourth quintile of $20 \%$, which is calculated by considering the share of income, earned $27 \%$ of total income. The average income of these farmer households was 1,584 kurus. Besli Mehmed from Bâzirgân Village with household number 88 was the wealthiest 
individual of the aforementioned quintile along with a total income of 1,580 kurus. When it comes to the households in the richest and the fifth quintile of $20 \%$, it is determined that the quintile received $37 \%$ of the total income. The average income of the farmer households in the fifth quintile was 2,200 kurus. As mentioned earlier, the richest individual among the households located in both regions was Hasan, the son of Deli Ali, who lived in Bâzirgân Village with household number 62.

The Gini coefficients and the relative poverty rates were also calculated by using the total income levels obtained by the households. According to the general level of the society, an individual or household with a level of income or expenditure below a certain limit is considered to be poor in a relative sense ${ }^{20}$ (Ravallion, 1998). In this context, the relative poverty line is found by using $50 \%$ of the median income. Hence, those that have a level of income below the limit are relatively poor. On the other hand, the level of income inequality is determined by Gini coefficient. Accordingly, the Gini coefficient is obtained by proportioning the area between the Lorenz Curve and the absolute equilibrium line to the area under the absolute equilibrium line. Table 4 indicates those values.

Table 4. Gini Coefficient and Relative Poverty Rate of Andugu and Kalkanli Counties

\begin{tabular}{|lc|}
\hline & Value \\
\hline Gini Coefficient & 0.3477 \\
\hline Relative Poverty Ratio & 0.24 \\
\hline
\end{tabular}

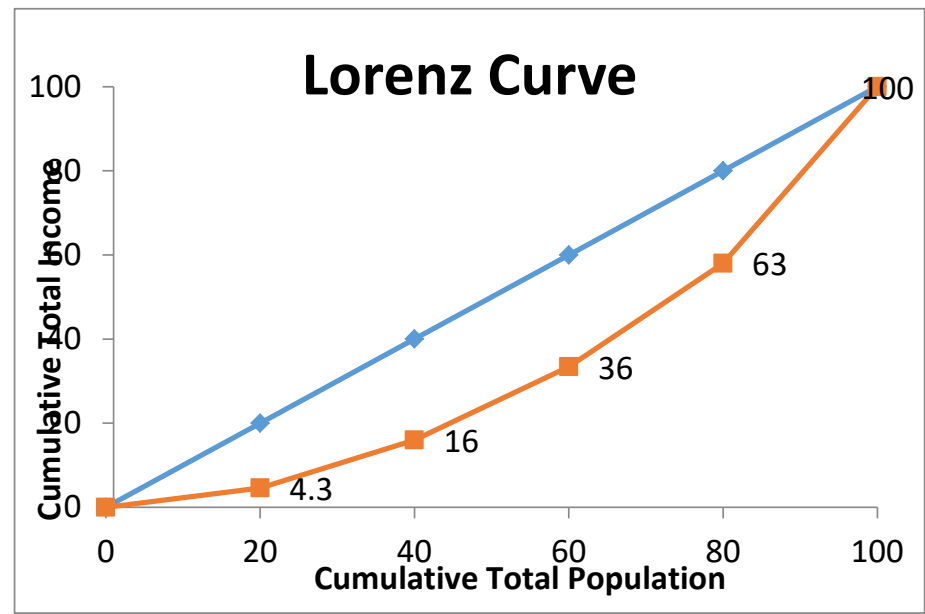

Figure 1. Lorenz Curve for Niğde Sanjak

${ }^{20}$ Martin Ravallion, 1998. 
An Economic Overview of Ottoman State Record of Taxes: Temettuat (Profit Tax) Registers of Niğde Sanjak (1844-1845)

According to the relative poverty analysis conducted on half of the median income, by taking the total income of the household resided in Andugu and Bâzirgân Villages of Niğde Sanjak into account, it is determined that 24\% of the households be poorer than the other households. The households below the poverty line were the ones with one muhtar and two workers, as well as other five households without any income. The other third household was above the poverty line.

\section{Tax Applications}

It was determined that the financial obligations collected in both settlements consist of vergi-i mahsusa (special tax), aşar ve rusûmât (tithe tax and duty charge) and âdet-i agnâm rusumu (small ruminant tax). Because of the changing taxation mentality with the the Imperial Edict of Gülhane, ancema'tin (commodity tax) levied and collected as dividend tax on income is explained in detail earlier. Until the Imperial Edict of Gülhane, the Ottoman tax system was gathered under such two main headings as shar'i taxes and customary taxes. Shar'i taxes are known to be based on religion, and they are divided into subheadings with different kinds and names such as zekât, ciftbozan, cizye, öşür, agnam, harac and ihtisap. Of the tax types mentioned above, the one that created the most burden on the reaya (non-Muslim subjects) was öşür.

The tax levied on the product is known as "harac-i mukaseme," while the agricultural and livestock taxes are notable as the items of this heading. Agricultural taxes are usually collected under the name of ösür at a rate of around $10 \%{ }^{21}$. The meaning of the word "öşür" means "one-tenth" 22 . In practice, however, the rate of tithe (öşür) had varied from one-tenth to one-fifth in different places, depending on the proportion of pre-existing taxes and the yield of land in different regions ${ }^{23}$. Tithe, originally known to be collected from Muslims as zekât of the crops of lands ${ }^{24}$, was about four times as much as the Ottoman State's tax revenues ${ }^{25}$. It was levied not only on the grain but also on all the soil products, gardens, vineyards and even hives ${ }^{26}$.

\footnotetext{
${ }^{21}$ Kazıc1 2014, p. 111; Tabakoğlu 2007, pp. 299-300.

${ }^{22}$ Başdemir 2015, p. 43; Devellioğlu, 2015, p. 996; Kütükoğlu, 1994, p. 531; Pakalın 1983, p. 746; Kamus-i Türki, p. 727; Tabakoğlu, 2007, XXXIV, p. 100.

${ }^{23}$ Kazıc1 2014, p. 112; Özbek 2015, p. 39; Pamuk 1990, p. 44; Şener 1990, p. 120.

${ }^{24}$ Süleyman Sudi 2008, p. 39.

${ }^{25}$ Eldem, 1994, p. 173; Varcan, 2000, p. 20.

${ }^{26}$ Pamuk 1990, p. 44.
} 
During the periods when the Timar system was not deteriorated, the tithe was collected by the reaya at the harvest season to be either stowed in the sipahi warehouse or taken to the market place upon request of the sipahi. Along with the deterioration of the economic conditions, the Timar system was rearranged according to the iltizam (land tenure) procedure, and the collection of the tithe was provided by the multezim (tax collectors). However, this situation had resulted in excessive financial burden inflicted on the reaya by the multezim for the sake of their personal interests. In fact, due to the high inflation experienced since the second half of the $16^{\text {th }}$ century, it was seen that the multezim entered into the usury activities by selling the agricultural products they collected as tithe on behalf of the State to the merchants at higher prices ${ }^{27}$. Nevertheless, in case of the good intentions of the multezim, agricultural losses appeared. That is because the multezim had not been able to collect the tithe at once, so they had tried to collect them in turns. In that case, the producers could have not harvested their crops because of the collection of the tithe, and they had to wait long periods. As a result, the agricultural product had been degraded due to external factors (rain, pests, birds, etc.) and the farmers had been in financial difficulties.

Along with the Imperial Edict of Gülhane, the rate of the tithe is fixed as one-tenth in accordance with the principle of equality. As a result, the productivity of tithe as an important tax item had decreased due to the deterioration of the land system and the efficiency was reduced. Finally, it was abolished by a law issued in 1925 following the Declaration of the Republic ${ }^{28}$.

Adet-i agnam (small ruminant tax), however, is derived from the plural form of the word "ganem (sheep)" which was synonym for "agnam resmi (small ruminant duty charge)" as one of the Sar-i taxes as well as "resm-i merai", "resm-i ganem" or "koyun resmi" mentioned in some laws of the Ottoman Empire ${ }^{29}$. Although agnam, as a Shar'i tax, was permissible to be collected on horse and cattle according to Shar'i ahkâm (legal provisions), it was also appropriate that these animals' due to their use in agriculture and transportation should had not been taxed on in the Ottoman State.

This duty charge collected on sheep and goats (including their lambs and kids) was paid a one akce per two-heads by the reaya breeders regardless of their settlements and religions.

\footnotetext{
${ }^{27}$ Kütükoğlu 1994, p. 532; Pamuk 1990, p. 104.

${ }^{28}$ Kütükoğlu 1994, p. 532.

${ }^{29}$ Çakır 2012, p. 52; Emecen, 1988, I, p. 478; Kazıc1 2014, p. 134; Kütükoğlu 1994, p. 538; Pamuk 1990, p. 44.
} 
An Economic Overview of Ottoman State Record of Taxes: Temettuat (Profit Tax)

Registers of Niğde Sanjak (1844-1845)

Although it had been collected as one akce per three sheep during the reign of Fatih Sultan Mehmed (the Conquerer), later on it was arranged as one akçe per two sheep ${ }^{30}$. Agnam resmi had differed according to the number of taxpayers (locals, nomads, or soldiers) or regions ${ }^{31}$.

However, there were two types of agnam in the Ottoman financial structure. The first one was "adet-i agnam" that had been collected since the Fatih era, and the other was the "decimal agnam" which started in $1826^{32}$. "Adet-i Agnam," despite its zekât qualities shown in the beginning, was combined with the "agil resmi" and collected in cash per small ruminant. On the other hand, "decimal agnam" that was coined during Mahmut the Second period, had been collected to meet the meat demands of the army and the capital city. This duty charge had been collected annually by authorized officers before the end of each fiscal year in cash or the in-kind equivalent of one-tenth of the existing sheep and goats. After presenting the basic characteristics of a household, the temettuat registers define the financial obligations of that household by describing the profession of the household head with the help of such statements as "the amount of special tax paid in the last year" and "the tithe tax and duty charge paid in a year."

In doing so, the household's income obtained from the livestock and other incomes along with the real estate and land incomes are registered in detail. These registers are like the "Household Budget Survey" studies being conducted by TSI.

In the analysis of tax payments made on income, it is seen that eight households in total did not pay any taxes. It is known that the five of these were exempted because of the absence of income and the fact that one of them was muhtar, as mentioned earlier. The remaining two households were recorded not to be paying taxes even though they had income. The notebook entries of the residents with household numbers 41 and 91 who lived in Bâzirgân Village are shown in Table 5.

\footnotetext{
${ }^{30}$ Kazıc1 2014, p. 135; Kütükoğlu 1994, p. 538.

${ }^{31}$ Sayın 1999, p. 27.

32 Kazıc1 2014, p. 137; Sayın 1999, p. 28.
} 
Table 5. Temettuat Registry of the Households Resided in Bâzirgân Village with Numbers 41 and 91 Molla Halil oglu Mustafa'nın Serîki Huseyin Aga'nın emlâk ve temettu'âtı:

Karye-i mezbûr ahâlîsinden idigi

Bir senede tahmînen temettu'âtı kurus: 305

Halil'in Serîki Hasan Efendi'nin emlâk ve temettu'âtı:

Bir senede tahmînen temettu'âtı kurus: 360

Source: BOA. ML. VRD. TMT. d. 10558

As it can be seen in Table 5, there is no recorded tax payment although both households had incomes. Even though income items were written on real estate and dividends, the absence of tax amount can be thought to be caused by the spelling error as well as from the exemption that the households had. Nonetheless, the highest tax rate on income was determined to be paid by Sari Huseyin, who resided in Bâzirgân Village with the household number 75. Table 6 indicates the temettuat registers of that household.

There exists extraordinary income of 400 kurus as well as 660 kurus which were obtained from the agricultural activities of the household. The amount of tax paid by the household which earned a total income of 1,040 kurus was recorded as 720 kurus along with the statement "the amount of special tax paid in the last year." However, since the household acquired cultivated fields, the sum of the tithe tax and duty charges levied on the obtained crops was 64 kurus. The household belonged to the third quintile when its place on income distribution is considered. In this context, it can be argued that the application of tax be unfair, given that the tax burden of the household was estimated at about $68 \%$. As a matter of fact, the tax burden arising from the inclusion of the paid tithe taxes and duty charges in the total financial liabilities reaches approximately $74 \%$.

Whether or not the commodity tax application which aims the fair distribution of taxation in society is eligible for this purpose can be determined by considering the distribution of tax burden in the society. Accordingly, determining what percentage of the income obtained is taxed and how the income is distributed among the income groups would determine the success level of the application. In this context, the amount of taxes paid by all the households and the ratios of those taxes to their income are shown in the appendix table. 
An Economic Overview of Ottoman State Record of Taxes: Temettuat (Profit Tax) Registers of Niğde Sanjak (1844-1845)

Table 6. Temettuat Registry of the Household Resided in Bâzirgân Village with Number 75

\begin{tabular}{|c|c|c|c|}
\hline arı Huseyin’in emlâk ve arâzî ve temettu'âtı: & & & \\
\hline Zirâ'at erbâbından idigi & & & \\
\hline Sene-i sâbıkada vergi-i mahsûsadan bir senede ver & s oldugu kurus & 720 & \\
\hline A'Sâr ve rusûmât olarak bir senede vermis oldugu & rus: & & \\
\hline $\begin{array}{l}\text { Hinta keyl: } 4 \\
(\text { Kiymet } 10=40)\end{array}$ & & $\begin{array}{l}\text { Sa'îr key } \\
\text { (Kiymet }\end{array}$ & $\begin{array}{l}1: 4 \\
6=24)\end{array}$ \\
\hline Yekûn 64 & & & \\
\hline $\begin{array}{l}\text { Mezra'a tarla dönum: } 10 \\
\text { (Hâsılât-1 senevî: } 640 \text { kurus } 60 \text { senesi }+500 \text { kurus } \\
\text { ber-vech-i tahmîn } 61 \text { senesi }=1140 \text { kurus) }\end{array}$ & $\begin{array}{l}\text { Gayr-1 } \\
\text { mezra'a } \\
\text { tarla dönum: } \\
10\end{array}$ & $\begin{array}{l}\text { Merkeb } \\
\text { re's: } 1\end{array}$ & $\begin{array}{l}\text { Sagman } \\
\text { inek re's: } \\
1 \\
\text { (Hâsılât-1 } \\
\text { senevî } \\
\text { kurus: } 20 \text { ) }\end{array}$ \\
\hline Bir senede tahmînen temettu'âtı kurus: & & & \\
\hline 660 & & & \\
\hline 400 & $\begin{array}{l}\text { Kereste ve ha } \\
\text { zuhûrât temet }\end{array}$ & $\begin{array}{l}\text { tab kat' } \\
\text { tu'âtı }\end{array}$ & an ve \\
\hline 1040 & & & \\
\hline
\end{tabular}

Source: BOA. ML. VRD. TMT. d. 10558

Given the tax rate calculated on the basis of income, it is seen that in practice, the tax rate of three percent, previously stated by Şener ${ }^{33}$, had not been realized in practice. As a matter of fact, the total income of Hasan, the orphan son of Haci Ahmed who resided in Andugu Village Karyesi, was 320 kurus while the tax he had paid was 165 kurus. Therefore, the average tax rate for that household was $51.5 \%$. Nevertheless, it can be argued that taxation be a regressive structure when it is considered that the household was located in the first poorest quintile of the income distribution. Similarly, the average tax rate for Ali from the household number 4, the son of Haci Aga, who belonged to the first poorest quintile, was 35\%; while it was 23\% for Topal Ahmed who lived in Bâzirgân Village with household number 17 as a worker. When all the households are taken into consideration, the average tax rate applied is calculated as $13.3 \%$. When the income and tax amounts of the households in the first poorest quintile of the income distribution are considered, the aforementioned unfair tax can be understood more clearly. For instance, Ismail, the son of Cin Osman who resided in Andugu Village with household number 36, had earned a total income of 306 kurus and paid 15 kurus as tax, while İbrahim, the son of Kasim who resided with

\footnotetext{
33 Şener 2007, p. 118.
} 
household number 26, had earned a total income of 110 kurus, and yet he also paid 15 kurus as tax.

Regarding the amount of taxes paid by the total incomes of the fifth richest quintile of income distribution, the regressive tax practice is detected again. In this context, Table 7 shows the taxes paid and the calculated average tax rates along with the total income levels of the households in the fifth richest quintile.

Table 7. The Average Tax Rates for the Households in the Fifth Richest Quintile

\begin{tabular}{|c|c|c|c|c|c|c|}
\hline Household & Occupation & $\begin{array}{c}\text { Agricultural } \\
\text { Revenue }\end{array}$ & $\begin{array}{c}\text { Other } \\
\text { Revenues }\end{array}$ & $\begin{array}{c}\text { Total } \\
\text { Revenue }\end{array}$ & Tax & $\begin{array}{c}\text { Average Tax } \\
\text { Rate }\end{array}$ \\
\hline 116 & Farmer & 865 & 900 & 1765 & 26 & 0.014731 \\
\hline 107 & Farmer & 1550 & 500 & 2050 & 118 & 0.057561 \\
\hline 40 & Farmer & 925 & 1000 & 1925 & 130 & 0.067533 \\
\hline 32 & Farmer & 1190 & 800 & 1990 & 165 & 0.082915 \\
\hline 100 & Farmer & 1560 & 1540 & 3100 & 276 & 0.089032 \\
\hline 65 & Farmer & 860 & 1000 & 1860 & 194 & 0.104301 \\
\hline 96 & Farmer & 1935 & 500 & 2435 & 272 & 0.111704 \\
\hline 43 & Farmer & 870 & 1700 & 2570 & 290 & 0.112841 \\
\hline 106 & Farmer & 1580 & 630 & 2210 & 250 & 0.113122 \\
\hline 2 & Farmer & 886 & 1700 & 2586 & 310 & 0.119876 \\
\hline 104 & Farmer & 760 & 1240 & 2000 & 250 & 0.125 \\
\hline 87 & Farmer & 880 & 1100 & 1980 & 252 & 0.127273 \\
\hline 84 & Farmer & 1170 & 1500 & 2670 & 350 & 0.131086 \\
\hline 108 & Farmer & 1100 & 1100 & 2200 & 290 & 0.131818 \\
\hline 82 & Farmer & 960 & 940 & 1900 & 256 & 0.134737 \\
\hline 39 & Farmer & 660 & 1340 & 2000 & 280 & 0.14 \\
\hline 66 & Farmer & 1000 & 1500 & 2500 & 350 & 0.14 \\
\hline 72 & Farmer & 940 & 900 & 1840 & 258 & 0.140217 \\
\hline 120 & Farmer & 700 & 1370 & 2070 & 292 & 0.141063 \\
\hline 112 & Farmer & 1160 & 1500 & 2660 & 376 & 0.141353 \\
\hline 81 & Farmer & 990 & 910 & 1900 & 272 & 0.143158 \\
\hline 61 & Farmer & 1220 & 1500 & 2720 & 390 & 0.143382 \\
\hline 95 & Farmer & 1330 & 1120 & 2450 & 365.5 & 0.149184 \\
\hline 56 & Farmer & 780 & 1000 & 1780 & 298 & 0.167416 \\
\hline 83 & Farmer & 1420 & 600 & 2020 & 354 & 0.175248 \\
\hline 44 & Farmer & 845 & 1160 & 2005 & 370 & 0.184539 \\
\hline
\end{tabular}

As shown in the table above, the average tax rates for the households in the fifth richest quintile range from $1.5 \%$ to $18.5 \%$. This situation is completely contradictory to the fair tax practice required to be introduced by the Imperial Edict of Gülhane. For example, Hasan, the son of Deli Ali, who was the richest 
household with 62 household number, had a total income of 3,100 kurus, while the dividend tax he paid was 276 kurus and the average tax rate was only $9 \%$. This is supported by the fact that the average tax rate for the households in the first poorest quintile was up to $68 \%$, and that the tax burden of the households in the fifth richest quintile was quite low. For example, following the exclusion of Hasan, the son of Cavus who resided in Bâzirgân Village with household number 78, from the tax-free households, he is found to have the lowest tax burden among 132 households, even though he occupied the fifth richest quintile. In this context, tax practices seem to be unfair in large measure.

The application of other financial obligations, such as the tithe tax and duty charges levied on crops, directly affects the total tax burden of the households. The tithe tax, which was to be paid in kind at $10 \%$ of the obtained product, essentially had a structure independent of income. In the study conducted on the tithe tax to be collected at $10 \%$ of the crops produced in both settlements, it is determined that in only eight households had paid tithe tax at $10 \%$, while eight households had paid tithe tax at a rate higher than $10 \%$. It is determined that six households had not paid any tithe tax due to the absence of any agricultural activity and the remaining 110 households had paid tithe tax at rates lower than $10 \%$. On the other hand, it is determined that 12 households had not paid any tithe tax even though they engaged in agricultural activities. The household with the highest amount of tithe paid was Haci Aga, the son of Ali who also resided in the household number 4 . In other words, it is estimated that aforementioned household had paid 52.5 kurus as tithe tax, although the amount of the agricultural income he earned was 130 kurus. Therefore, it is quite striking that the household number 4 had paid both the dividend and the tithe tax at higher rates. The lowest rate among the tithe tax-payers is approximately $0.5 \%$. As a matter of fact, when all the digits are taken into consideration, it is calculated that the applied average ratio is $8 \%$.

\section{Conclusion}

The 19th century was full of intertwined phenomena such as struggles, crises, defeats, changes, and reforms for the Ottoman State. On the one hand, the weakening of the state administration, the battles with heavy defeats, the worsening of the economy; on the other hand, the beginning of the debate on the idea of reform and radical changes rendered the 19th century as the most devastating period regarding the Ottoman State.

The worsening of the fiscal system and the chronicity of the crises, which corresponded to the decline of the state, has brought the State to the stage of 
disintegration. The main reason underlying the change process that caused the Ottoman Empire to be degraded from "Devlet-i aliyye-i ebed-muddet (Great, ever-lasting state)" to the "sick man of Europe" was the weakening of the fiscal system.

The incidence of corruption, bribery, and favoritism has increased steadily with the lack of prudent statesmen in state administration, and some reformist practices have finally come to fruition. Among these, the declaration of the Imperial Edict of Gülhane had the greatest impact both in administrative and financial terms. To prevent the tax losses in the presence of the financial system with this edict, the commodity tax was applied, and all tax items were kept in a notebook. The socioeconomic status of Bâzirgân and Ortakoy Villages within Andugu and Kalkanli counties of Niğde Sanjak in Karaman province was analysed in the context of these records, which were called "Temettuat Tahrirleri" (Temettuat -Profit Tax- Registers).

Within the scope of the study, income distribution and relative poverty rates of 132 households are determined. There are 38 households in the notebooks belonging to, Ortakoy Village within Andugu County; while there are 94 households in Bâzirgân Village within Kalkanli County. The temettuat registers, belonging to both settlements between the years 1844-1845, are obtained from the Ottoman Archives of the Prime Minister' Office.

In the study conducted on a total of 132 households, the average income per household was 1,160,78 kurus, while the lowest income was 0 and the highest income was 3,100 kurus. Generally, the earned incomes are obtained from agricultural activities and livestock breeding. There are also five households in the notebooks with no income at all. Upon examining the household according to the profession groups, there were 120 farmers, three worker households, one soldier household, one divane household, one muhtar (village headman) household and six households with other professions.

When agricultural incomes obtained by the households are examined, the average agricultural income per household is calculated as approximately 605 kurus. The agricultural gains achieved by $53 \%$ of the surveyed households were below the average. However, when the 20\% distribution quintiles are considered, the households in the first poorest quintile can only take $4.3 \%$ of the total estimated income registered in temettuat registers. A total of 27 households were identified in the first poorest quintile. Nevertheless, the fifth richest quintile is found to be $37 \%$ of total income, and the average income was 2,200 kurus. 
An Economic Overview of Ottoman State Record of Taxes: Temettuat (Profit Tax)

Registers of Niğde Sanjak (1844-1845)

Consequently, $24 \%$ of the households are found to be poorer than the other households in accordance with the relative poverty analysis performed on the half of the median income by considering the total income of the households resided in Andugu and Bâzirgân Villages of Niğde Sanjak. The Gini coefficient calculation for the aforementioned settlements is determined as 0.33477 . 


\section{Ali Gökhan GÖLÇEK - Altuğ Murat KÖKTAŞ}

\section{BIBLIOGRAPHY}

\section{Archival Sources:}

Başbakanlık Osmanlı Arşivi, Başbakanlık Osmanlı Arşivi Rehberi (Ed. İ. Genç and others.). İstanbul: Başbakanlık Basımevi 2010.

Başbakanlık Osmanlı Arşivi, ML. VRD. TMT. d. 10558.

Başbakanlık Osmanlı Arşivi, ML. VRD. TMT. d. 15982.

\section{Published Sources and Works:}

Agoston 2006 Gabor Agoston, Barut, Top ve Tüfek (Translated by T. Akad). İstanbul: Kitap Yayınevi.

Akbal $1951 \quad$ Fazıla Akbal, "1831 Tarihindeki Osmanlı İmparatorluğunda

Akşit 2009 İdari Taksimat ve Nüfus”, Belleten, XV, 60, pp. 617-628.

Aktüre 1975 Ahmet Akşit, "Akmedrese Vakfiye: Historical Sources About Niğde City”, Journal of Turkology Research, 26, pp. 21-28.

Sevgi Aktüre, "17. Yüzyıl Başından 19. Yüzyıl Ortasına Kadarki Dönemde Anadolu Osmanlı Şehrinde Şehirsel Yapının Değişme Süreci", M.E.T.U. Journal of The Faculty of Architecture, I, 1, pp. 1-28.

Başdemir 2015

Baykal Başdemir, Osmanlı Vergi Sisteminde Öşür. Adana: Karahan Kitabevi.

Çakır 2012

Coşkun Çakır, Tanzimat Dönemi Osmanlı Maliyesi. İstanbul: Küre Yayınları.

Devellioğlu 2015 Ferit Devellioğlu, Osmalıca-Türkçe Ansiklopedik Lügat. Ankara: Aydın Kitabevi Yayınları 2015.

Eldem 1994

Emecen 1988 Vedat Eldem, Osmanlı Imparatorluğu’nun İktisadi Şartları Hakkında Bir Tetkik. Ankara: Türk Tarih Kurumu Basımevi. Feridun Emecen, "Ağnam Resmi", Türkiye Diyanet Vakfi Íslam Ansiklopedisi, I, pp. 478-479.

Galanti 1951

Güran 2000 Avram Galanti, Niğde ve Bor Tarihi. İstanbul: Tan Matbaası. Tevfik Güran, "19. Yüzyıl Temettüat Tahrirleri”, in Osmanlı Devleti'nde Bilgi ve İstatistik (Ed. H. İnalcık \& Ş. Pamuk). Ankara: T.C. Başbakanlık Devlet İstatistik Enstitüsü Yayınları, pp. 73-94.

Güran 2014

Tevfik Güran, 19. Yüzyllda Osmanlı Ekonomisi Üzerine Araştırmalar. İstanbul: Türkiye İş Bankası Kültür Yayınları.

Güven 2004 Cemal Güven, "Niğde-Bor Bölgesinin 1794-1799 Yılları Arasındaki Askeri Yükümlülükleri (387 No'lu Bor Şer'iyye Siciline Göre)”, Selçuk Üniversitesi Sosyal Bilimler Enstitüsü Dergisi, 11, pp. 391-405. 
An Economic Overview of Ottoman State Record of Taxes: Temettuat (Profit Tax)

Registers of Niğde Sanjak (1844-1845)

Kamus-i Türki

Şemseddin Sami, Kamus-i Türki (Ed. R. Gündoğdu and others), İstanbul: İdeal Kültür Yayıncılık, 2015

Karpat 2003

Kemal Karpat, Osmanlı Nüfusu (1830-1914). İstanbul: Tarih Vakfi Yayınları.

Kaya 2006

Mehmet Kaya, "About the Population of Niğde Sancak at the Beginnings of the 20th Century", Journal of Studies in Turcology, 19, pp. 193-210.

Kaynar 1991

Reşat Kaynar, Mustafa Reşit Paşa ve Tanzimat. Ankara: Türk Tarih Kurumu Yayınları.

Kazıc1 2014

Kütükoğlu 1994

Ziya Kazıc1, Osmanlı'da Vergi Sistemi. İstanbul: Kayıhan Yayınları.

Mübahat Kütükoğlu, "Osmanlı İktisadi Yapısı" in Osmanl Devleti ve Medeniyeti Tarihi I. İstanbul: İslam Tarih, Sanat ve Kültür Araştırma Merkezi, pp. 513-547.

Metin 2016

Rafet Metin, "An Evaluation on the Demographic Structure of Niğde Province in XVI Century”, The Journal of Academic Social Science Studies, 45, pp. 35-52.

Oflaz 2007

Mustafa Oflaz, "Niğde”, Türkiye Diyanet Vakfi İslam Ansiklopedisi, 33, pp. 92-95.

Özbek 2015

Öztuna 1997

Pakalın 1983

Pamuk 1990

Ravallion 1998

Nadir Özbek, Imparatorluğun Bedeli. İstanbul: Boğaziçi Üniversitesi Yayınevi.

Yılmaz Öztuna, Büyük Türkiye Tarihi I. İstanbul: Ötüken Yayınevi.

M. Zeki Pakalın, Osmanl Tarih Deyimleri ve Terimleri Sözlüğü. İstanbul: Milli Eğitim Basımevi.

Şevket Pamuk, 100 Soruda Osmanll-Türkiye Íktisadi Tarihi 1500-1914. İstanbul: Gerçek Yayınevi.

Martin Ravallion, Poverty Lines in Theory and Practice, Washington: LMS Working Paper.

Sakal ve Gölçek 2017 Mustafa Sakal -Ali Gökhan Gölçek, "Financial Crisis and Reform in the Ottoman State”, Sosyoekonomi, vol. 25, 34, pp. 11-32.

Sayın 1999

A. Vefik Sayın, Tekalif Kavaidi (Translated by F. H. Özkan). Ankara: T.C. Maliye Bakanlığı Araştırma, Planlama ve Koordinasyon Kurulu Başkanlığı Yayınları.

Selçuk 2013

Şener 1990

Havva Selçuk, "First Population Census in Niğde (Shawwal 23, 1246 / April 6, 1831)”, The Journal of Academic Social Science Studies, VI, 2, pp. 1263-1294.

Abdüllatif Şener, Tanzimat Dönemi Osmanlı Vergi Sistemi. Ankara: İşaret Yayınları. 
Şener 2007

Sudi 2008

Tabakoğlu 2007

Tabakoğlu 2014

Uzunçarş11 1995

Varcan 2000
Abdüllatif Şener, Sona Doğru Osmanlı. Ankara: Birleşik Kitabevi.

Süleyman Sudi, Defter-i Muktesid (Ed. M. Ünal). Isparta: Fakülte Kitabevi.

Ahmet Tabakoğlu, "Öşür", Türkiye Diyanet Vakfi İslam Ansiklopedisi, XXXIV, pp. 100-103.

Ahmet Tabakoğlu, Türkiye İktisat Tarihi. İstanbul: Dergâh Yayınları.

İsmail Hakkı Uzunçarşıll, Osmanlı Tarihi I. Ankara: Türk Tarih Kurumu Yayınları.

Nezih Varcan, Osmanlı Maliyesi Hakkinda Ingiliz Raporlart. Ankara, T.C. Maliye Bakanlığ 1 Araştırma, Planlama ve Koordinasyon Kurulu Başkanlığı Yayınları.

Appendix: Income, Tax and Tithe-Duty Charge Records of the Households along with Average Tax Rate and Total Tax Burden Rates

\begin{tabular}{|c|c|c|c|c|c|c|c|c|c|c|}
\hline $\begin{array}{c}\text { Househol } \\
\mathbf{d}\end{array}$ & $\begin{array}{c}\text { Agricultura } \\
\mathbf{l} \\
\text { Revenue }\end{array}$ & $\begin{array}{c}\text { Other } \\
\text { Revenue } \\
\mathbf{s}\end{array}$ & $\begin{array}{c}\text { Total } \\
\text { Revenu } \\
\mathbf{e}\end{array}$ & $\mathbf{T a x}$ & $\begin{array}{c}\text { Tith } \\
\mathbf{e}\end{array}$ & $\begin{array}{c}\text { Small } \\
\text { Ruminan } \\
\mathbf{t}\end{array}$ & $\begin{array}{c}\text { Total } \\
\text { Financial } \\
\text { Obligations }\end{array}$ & $\begin{array}{c}\text { Income } \\
\text { Quintil } \\
\mathbf{e}\end{array}$ & $\begin{array}{c}\text { Average } \\
\text { Tax } \\
\text { Rate }\end{array}$ & $\begin{array}{c}\text { Total } \\
\text { Burden }\end{array}$ \\
\hline 79 & 305 & 0 & 305 & 0 & 0 & 0 & 0 & 1 & 0 & 0 \\
\hline 91 & 475 & 0 & 475 & 0 & 0 & 0 & 0 & 2 & 0 & 0 \\
\hline 129 & 360 & 0 & 360 & 0 & 0 & 0 & 0 & 1 & 0 & 0 \\
\hline 29 & 0 & 0 & 0 & 0 & 0 & 0 & 0 & 1 & 0 & 0 \\
\hline 34 & 0 & 0 & 0 & 0 & 0 & 0 & 0 & 1 & 0 & 0 \\
\hline 38 & 0 & 0 & 0 & 0 & 0 & 0 & 0 & 1 & 0 & 0 \\
\hline 89 & 0 & 0 & 0 & 0 & 0 & 0 & 0 & 1 & 0 & 0 \\
\hline 131 & 0 & 0 & 0 & 0 & 0 & 0 & 0 & 1 & 0 & 0 \\
\hline 128 & 400 & 600 & 1000 & 44 & 0 & 0 & 44 & 3 & 0.044 & 0.044 \\
\hline 36 & 6 & 300 & 306 & 15 & 0 & 0 & 15 & 1 & 0.04902 & 0.04902 \\
\hline 116 & 865 & 900 & 1765 & 26 & 74 & 0 & 100 & 5 & 0.014731 & 0.05665 \\
7 \\
\hline 122 & 20 & 680 & 700 & 50 & 0 & 0 & 50 & 2 & 0.071429 & 0.07142 \\
9 \\
\hline 20 & 22 & 350 & 372 & 35 & 1 & 0 & 36 & 1 & 0.094086 & 0.09677 \\
4 \\
\hline 6
\end{tabular}


An Economic Overview of Ottoman State Record of Taxes: Temettuat (Profit Tax) Registers of Niğde Sanjak (1844-1845)

\begin{tabular}{|c|c|c|c|c|c|c|c|c|c|c|}
\hline 7 & 460 & 0 & 460 & 25 & 32 & 0 & 57 & 2 & 0.054348 & $\begin{array}{c}0.12391 \\
3 \\
\end{array}$ \\
\hline 107 & 1550 & 500 & 2050 & 118 & 148 & 0 & 266 & 5 & 0.057561 & $\begin{array}{c}0.12975 \\
6\end{array}$ \\
\hline 35 & 45 & 155 & 200 & 25 & 1 & 0 & 26 & 1 & 0.125 & 0.13 \\
\hline 123 & 520 & 0 & 520 & 38 & 30 & 0 & 68 & 2 & 0.073077 & $\begin{array}{c}0.13076 \\
9\end{array}$ \\
\hline 121 & 460 & 300 & 760 & 60 & 40 & 0 & 100 & 2 & 0.078947 & $\begin{array}{c}0.13157 \\
9 \\
\end{array}$ \\
\hline 45 & 450 & 1200 & 1650 & 178 & 40 & 0 & 218 & 4 & 0.107879 & $\begin{array}{c}0.13212 \\
1 \\
\end{array}$ \\
\hline 25 & 430 & 300 & 730 & 55 & 41.5 & 0 & 96.5 & 2 & 0.075343 & $\begin{array}{c}0.13219 \\
2 \\
\end{array}$ \\
\hline 126 & 780 & 800 & 1580 & 150 & 60 & 0 & 210 & 4 & 0.094937 & $\begin{array}{c}0.13291 \\
1 \\
\end{array}$ \\
\hline 58 & 75 & 600 & 675 & 90 & 0 & 0 & 90 & 2 & 0.133333 & $\begin{array}{c}0.13333 \\
3 \\
\end{array}$ \\
\hline 32 & 1190 & 800 & 1990 & 165 & 101 & 0 & 266 & 5 & 0.082915 & $\begin{array}{c}0.13366 \\
8 \\
\end{array}$ \\
\hline 27 & 50 & 150 & 200 & 25 & 2 & 0 & 27 & 1 & 0.125 & 0.135 \\
\hline 51 & 250 & 0 & 250 & 34 & 0 & 0 & 34 & 1 & 0.136 & 0.136 \\
\hline 26 & 10 & 100 & 110 & 15 & 0 & 0 & 15.5 & 1 & 0.136364 & $\begin{array}{c}0.13636 \\
4\end{array}$ \\
\hline 86 & 625 & 295 & 920 & 79 & 48 & 0 & 127 & 3 & 0.08587 & $\begin{array}{c}0.13804 \\
4 \\
\end{array}$ \\
\hline 19 & 378 & 250 & 628 & 55 & 31.7 & 0 & 86.7 & 2 & 0.08758 & $\begin{array}{c}0.13805 \\
7 \\
\end{array}$ \\
\hline 22 & 45 & 800 & 845 & 115 & 2.5 & 0 & 117.5 & 2 & 0.136095 & $\begin{array}{c}0.13905 \\
3\end{array}$ \\
\hline 125 & 440 & 980 & 1420 & 155 & 42 & 1 & 198 & 4 & 0.109155 & $\begin{array}{c}0.13943 \\
7 \\
\end{array}$ \\
\hline 31 & 55 & 150 & 205 & 25 & 4 & 0 & 29 & 1 & 0.121951 & $\begin{array}{c}0.14146 \\
3 \\
\end{array}$ \\
\hline 12 & 240 & 700 & 940 & 110 & 23.5 & 0 & 133.5 & 3 & 0.117021 & $\begin{array}{c}0.14202 \\
1\end{array}$ \\
\hline 118 & 420 & 380 & 800 & 72 & 42 & 0 & 114 & 2 & 0.09 & 0.1425 \\
\hline 92 & 240 & 380 & 620 & 65 & 24 & 0 & 89 & 2 & 0.104839 & $\begin{array}{c}0.14354 \\
8 \\
\end{array}$ \\
\hline 43 & 870 & 1700 & 2570 & 290 & 80 & 0 & 370 & 5 & 0.112841 & $\begin{array}{c}0.14396 \\
9\end{array}$ \\
\hline 65 & 860 & 1000 & 1860 & 194 & 74 & 0 & 268 & 5 & 0.104301 & $\begin{array}{c}0.14408 \\
6\end{array}$ \\
\hline 8 & 420 & 1200 & 1620 & 210 & 24.5 & 1 & 235.5 & 4 & 0.12963 & 0.14537 \\
\hline 2 & 886 & 1700 & 2586 & 310 & 64.5 & 3.5 & 378 & 5 & 0.119876 & $\begin{array}{c}0.14617 \\
2 \\
\end{array}$ \\
\hline 94 & 850 & 800 & 1650 & 162 & 80 & 0 & 242 & 4 & 0.098182 & $\begin{array}{c}0.14666 \\
7 \\
\end{array}$ \\
\hline 130 & 420 & 240 & 660 & 59 & 38 & 1 & 98 & 2 & 0.089394 & $\begin{array}{c}0.14848 \\
5 \\
\end{array}$ \\
\hline 85 & 350 & 830 & 1180 & 144 & 35 & 0 & 179 & 3 & 0.122034 & $\begin{array}{c}0.15169 \\
5\end{array}$ \\
\hline 37 & 346 & 1000 & 1346 & 175 & 30.5 & 0 & 205.5 & 3 & 0.130015 & $\begin{array}{c}0.15267 \\
5\end{array}$ \\
\hline 24 & 430 & 400 & 830 & 85 & 41.8 & 0 & 126.8 & 2 & 0.10241 & $\begin{array}{c}0.15277 \\
1\end{array}$ \\
\hline
\end{tabular}




\section{Ali Gökhan GÖLÇEK - Altuğ Murat KÖKTAŞ}

\begin{tabular}{|c|c|c|c|c|c|c|c|c|c|c|}
\hline 50 & 740 & 720 & 1460 & 160 & 64 & 0 & 224 & 4 & 0.109589 & $\begin{array}{c}0.15342 \\
5 \\
\end{array}$ \\
\hline 101 & 525 & 1000 & 1525 & 186 & 46 & 2 & 234 & 4 & 0.121967 & $\begin{array}{c}0.15344 \\
3\end{array}$ \\
\hline 67 & 570 & 1000 & 1570 & 194 & 48 & 2 & 244 & 4 & 0.123567 & $\begin{array}{c}0.15541 \\
4\end{array}$ \\
\hline 33 & 85 & 650 & 735 & 110 & 5 & 0 & 115 & 2 & 0.14966 & $\begin{array}{c}0.15646 \\
3\end{array}$ \\
\hline 78 & 425 & 1000 & 1425 & 164 & 61 & 0 & 225 & 4 & 0.115088 & $\begin{array}{c}0.15789 \\
5 \\
\end{array}$ \\
\hline 114 & 720 & 330 & 1050 & 96 & 70 & 0 & 166 & 3 & 0.091429 & $\begin{array}{c}0.15809 \\
5\end{array}$ \\
\hline 117 & 540 & 410 & 950 & 99 & 52 & 0 & 151 & 3 & 0.104211 & $\begin{array}{c}0.15894 \\
7\end{array}$ \\
\hline 52 & 355 & 900 & 1255 & 162 & 38 & 0 & 200 & 3 & 0.129084 & $\begin{array}{c}0.15936 \\
3\end{array}$ \\
\hline 103 & 520 & 420 & 940 & 98 & 50 & 2 & 150 & 3 & 0.104255 & $\begin{array}{c}0.15957 \\
5\end{array}$ \\
\hline 46 & 420 & 800 & 1220 & 156 & 40 & 0 & 196 & 3 & 0.127869 & $\begin{array}{c}0.16065 \\
6 \\
\end{array}$ \\
\hline 105 & 765 & 900 & 1665 & 196 & 74 & 0 & 270 & 4 & 0.117718 & $\begin{array}{c}0.16216 \\
2 \\
\end{array}$ \\
\hline 119 & 645 & 900 & 1545 & 194 & 52 & 5 & 251 & 4 & \begin{tabular}{|l|}
0.125566 \\
\end{tabular} & 0.16246 \\
\hline 57 & 20 & 300 & 320 & 52 & 0 & 0 & 52 & 1 & 0.1625 & 0.1625 \\
\hline 99 & 1119 & 500 & 1619 & 170 & 94 & 0 & 264 & 4 & 0.105003 & $\begin{array}{c}0.16306 \\
4\end{array}$ \\
\hline 110 & 370 & 200 & 570 & 60 & 30 & 3 & 93 & 2 & 0.105263 & $\begin{array}{c}0.16315 \\
8\end{array}$ \\
\hline 104 & 760 & 1240 & 2000 & 250 & 74 & 3 & 327 & 5 & 0.125 & 0.1635 \\
\hline 23 & 70 & 800 & 870 & 140 & 2.5 & 0 & 142.5 & 2 & 0.16092 & $\begin{array}{c}0.16379 \\
3 \\
\end{array}$ \\
\hline 109 & 810 & 860 & 1670 & 200 & 74 & 0 & 274 & 4 & 0.119761 & $\begin{array}{c}0.16407 \\
2 \\
\end{array}$ \\
\hline 14 & 95 & 1000 & 1095 & 175 & 8.5 & 0 & 183.5 & 3 & 0.159817 & 0.16758 \\
\hline 84 & 1170 & 1500 & 2670 & 350 & 88 & 12 & 450 & 5 & 0.131086 & $\begin{array}{c}0.16853 \\
9 \\
\end{array}$ \\
\hline 120 & 700 & 1370 & 2070 & 292 & 55 & 2 & 349 & 5 & 0.141063 & $\begin{array}{c}0.16859 \\
9\end{array}$ \\
\hline 97 & 590 & 0 & 590 & 50 & 50 & 0 & 100 & 2 & 0.084746 & $\begin{array}{c}0.16949 \\
2\end{array}$ \\
\hline 87 & 880 & 1100 & 1980 & 252 & 82 & 2 & 336 & 5 & 0.127273 & $\begin{array}{c}0.16969 \\
7 \\
\end{array}$ \\
\hline 115 & 390 & 610 & 1000 & 138 & 32 & 0 & 170 & 3 & 0.138 & 0.17 \\
\hline 102 & 880 & 700 & 1580 & 190 & 80 & 0 & 270 & 4 & 0.120253 & $\begin{array}{c}0.17088 \\
6\end{array}$ \\
\hline 124 & 220 & 200 & 420 & 50 & 22 & 0 & 72 & 1 & \begin{tabular}{|l|l|}
0.119048 \\
\end{tabular} & $\begin{array}{c}0.17142 \\
9 \\
\end{array}$ \\
\hline 42 & 710 & 250 & 960 & 101 & 64 & 0 & 165 & 3 & 0.105208 & $\begin{array}{c}0.17187 \\
5\end{array}$ \\
\hline 49 & 257 & 150 & 407 & 50 & 20 & 0 & 70 & 1 & \begin{tabular}{|l|}
0.12285 \\
\end{tabular} & 0.17199 \\
\hline 39 & 660 & 1340 & 2000 & 280 & 64 & 0 & 344 & 5 & 0.14 & 0.172 \\
\hline 96 & 1935 & 500 & 2435 & 272 & 148 & 0 & 420 & 5 & 0.111704 & $\begin{array}{c}0.17248 \\
5\end{array}$ \\
\hline 21 & 640 & 500 & 1140 & 135 & 62 & 0 & 197 & 3 & 0.118421 & $\begin{array}{c}0.17280 \\
7\end{array}$ \\
\hline
\end{tabular}


An Economic Overview of Ottoman State Record of Taxes: Temettuat (Profit Tax) Registers of Niğde Sanjak (1844-1845)

\begin{tabular}{|c|c|c|c|c|c|c|c|c|c|c|}
\hline 88 & 830 & 600 & 1430 & 178 & 70 & 0 & 248 & 4 & 0.124476 & $\begin{array}{c}0.17342 \\
7\end{array}$ \\
\hline 106 & 1580 & 630 & 2210 & 250 & 136 & 0 & 386 & 5 & 0.113122 & $\begin{array}{c}0.17466 \\
1\end{array}$ \\
\hline 75 & 720 & 1000 & 1720 & 231 & 70 & 0 & 301 & 4 & 0.134302 & 0.175 \\
\hline 108 & 1100 & 1100 & 2200 & 290 & 98 & 0 & 388 & 5 & 0.131818 & $\begin{array}{c}0.17636 \\
4\end{array}$ \\
\hline 11 & 265 & 500 & 765 & 110 & 25 & 0 & 135 & 2 & 0.143791 & $\begin{array}{c}0.17647 \\
1\end{array}$ \\
\hline 59 & 780 & 500 & 1280 & 156 & 70 & 0 & 226 & 3 & 0.121875 & $\begin{array}{c}0.17656 \\
3\end{array}$ \\
\hline 66 & 1000 & 1500 & 2500 & 350 & 96 & 1 & 447 & 5 & 0.14 & 0.1788 \\
\hline 82 & 960 & 940 & 1900 & 256 & 84 & 0 & 340 & 5 & 0.134737 & $\begin{array}{c}0.17894 \\
7\end{array}$ \\
\hline 54 & 975 & 750 & 1725 & 220 & 84 & 5 & 309 & 4 & 0.127536 & 0.17913 \\
\hline 15 & 25 & 120 & 145 & 25 & 1 & 0 & 26 & 1 & 0.172414 & 0.17931 \\
\hline 61 & 1220 & 1500 & 2720 & 390 & 100 & 4 & 494 & 5 & 0.143382 & $\begin{array}{c}0.18161 \\
8\end{array}$ \\
\hline 9 & 489 & 900 & 1389 & 210 & 42 & 0.5 & 252.5 & 3 & 0.151188 & $\begin{array}{c}0.18178 \\
6\end{array}$ \\
\hline 127 & 440 & 0 & 440 & 38 & 42 & 0 & 80 & 1 & 0.086364 & $\begin{array}{c}0.18181 \\
8\end{array}$ \\
\hline 68 & 650 & 500 & 1150 & 152 & 58 & 0 & 210 & 3 & 0.132174 & $\begin{array}{c}0.18260 \\
9 \\
\end{array}$ \\
\hline 112 & 1160 & 1500 & 2660 & 376 & 110 & 2 & 488 & 5 & 0.141353 & $\begin{array}{c}0.18345 \\
9\end{array}$ \\
\hline 72 & 940 & 900 & 1840 & 258 & 80 & 0 & 338 & 5 & 0.140217 & $\begin{array}{c}0.18369 \\
6 \\
\end{array}$ \\
\hline 30 & 130 & 500 & 630 & 110 & 6 & 0 & 116 & 2 & 0.174603 & $\begin{array}{c}0.18412 \\
7\end{array}$ \\
\hline 132 & 240 & 560 & 800 & 124 & 24 & 0 & 148 & 2 & 0.155 & 0.185 \\
\hline 77 & 840 & 500 & 1340 & 175 & 74 & 0 & 249 & 3 & 0.130597 & $\begin{array}{c}0.18582 \\
1\end{array}$ \\
\hline 18 & 625 & 300 & 925 & 110 & 62.5 & 0 & 172.5 & 3 & 0.118919 & $\begin{array}{c}0.18648 \\
7 \\
\end{array}$ \\
\hline 81 & 990 & 910 & 1900 & 272 & 87 & 0 & 359 & 5 & 0.143158 & $\begin{array}{c}0.18894 \\
7 \\
\end{array}$ \\
\hline 76 & 690 & 210 & 900 & 108 & 63 & 0 & 171 & 2 & 0.12 & 0.19 \\
\hline 90 & 615 & 800 & 1415 & 174 & 95 & 0 & 269 & 3 & 0.122968 & $\begin{array}{c}0.19010 \\
6\end{array}$ \\
\hline 10 & 360 & 700 & 1060 & 175 & 27 & 0 & 205 & 3 & 0.165094 & $\begin{array}{c}0.19056 \\
6 \\
\end{array}$ \\
\hline 98 & 980 & 740 & 1720 & 240 & 88 & 0 & 328 & 4 & 0.139535 & $\begin{array}{c}0.19069 \\
8\end{array}$ \\
\hline 74 & 610 & 900 & 1510 & 231 & 58 & 3 & 292 & 4 & 0.15298 & $\begin{array}{c}0.19337 \\
8\end{array}$ \\
\hline 13 & 300 & 400 & 700 & 110 & 25.5 & 0 & 135.5 & 2 & 0.157143 & $\begin{array}{c}0.19357 \\
1 \\
\end{array}$ \\
\hline 95 & 1330 & 1120 & 2450 & $\begin{array}{c}365 . \\
5\end{array}$ & 116 & 0 & 481.5 & 5 & 0.149184 & $\begin{array}{c}0.19653 \\
1\end{array}$ \\
\hline 17 & 290 & 150 & 440 & 55 & 31.5 & 0 & 86.5 & 1 & 0.125 & $\begin{array}{c}0.19659 \\
1\end{array}$ \\
\hline 41 & 1130 & 560 & 1690 & 240 & 111 & 0 & 351 & 4 & 0.142012 & $\begin{array}{c}0.20769 \\
2 \\
\end{array}$ \\
\hline 47 & 490 & 1010 & 1500 & 270 & 44 & 0 & 314 & 4 & 0.18 & $\begin{array}{c}0.20933 \\
3 \\
\end{array}$ \\
\hline
\end{tabular}




\section{Ali Gökhan GÖLÇEK - Altuğ Murat KÖKTAŞ}

\begin{tabular}{|c|c|c|c|c|c|c|c|c|c|c|}
\hline 1 & 160 & 0 & 160 & 25 & 8.5 & 0 & 33.5 & 1 & 0.15625 & $\begin{array}{c}0.20937 \\
5\end{array}$ \\
\hline 56 & 780 & 1000 & 1780 & 298 & 74 & 1 & 373 & 5 & 0.167416 & $\begin{array}{c}0.20955 \\
1 \\
\end{array}$ \\
\hline 53 & 690 & 980 & 1670 & 290 & 62 & 3 & 355 & 4 & 0.173653 & $\begin{array}{c}0.21257 \\
5\end{array}$ \\
\hline 64 & 750 & 0 & 750 & 90 & 70 & 0 & 160 & 2 & 0.12 & $\begin{array}{c}0.21333 \\
3 \\
\end{array}$ \\
\hline 62 & 840 & 160 & 1000 & 150 & 64 & 0 & 214 & 3 & 0.15 & 0.214 \\
\hline 70 & 120 & 500 & 620 & 120 & 15 & 0 & 135 & 2 & 0.193548 & $\begin{array}{c}0.21774 \\
2 \\
\end{array}$ \\
\hline 73 & 700 & 760 & 1460 & 256 & 60 & 4 & 320 & 4 & 0.175343 & $\begin{array}{c}0.21917 \\
8 \\
\end{array}$ \\
\hline 48 & 580 & 520 & 1100 & 184 & 58 & 0 & 242 & 3 & 0.167273 & 0.22 \\
\hline 44 & 845 & 1160 & 2005 & 370 & 75 & 0 & 445 & 5 & 0.184539 & $\begin{array}{c}0.22194 \\
5\end{array}$ \\
\hline 80 & 800 & 800 & 1600 & 286 & 80 & 0 & 366 & 4 & 0.17875 & 0.22875 \\
\hline 55 & 20 & 320 & 340 & 78 & 0 & 0 & 78 & 1 & 0.229412 & $\begin{array}{c}0.22941 \\
2 \\
\end{array}$ \\
\hline 3 & 530 & 0 & 530 & 45 & 77 & 1.5 & 123.5 & 2 & 0.084906 & $\begin{array}{c}0.23301 \\
9 \\
\end{array}$ \\
\hline 83 & 1420 & 600 & 2020 & 354 & 126 & 0 & 480 & 5 & 0.175248 & $\begin{array}{c}0.23762 \\
4\end{array}$ \\
\hline 71 & 750 & 650 & 1400 & 260 & 80 & 0 & 340 & 3 & 0.185714 & $\begin{array}{c}0.24285 \\
7 \\
\end{array}$ \\
\hline 60 & 660 & 330 & 990 & 188 & 54 & 0 & 242 & 3 & 0.189899 & $\begin{array}{c}0.24444 \\
4 \\
\end{array}$ \\
\hline 69 & 780 & 550 & 1330 & 280 & 76 & 0 & 356 & 3 & 0.210526 & $\begin{array}{c}0.26766 \\
9 \\
\end{array}$ \\
\hline 111 & 0 & 600 & 600 & 120 & 74 & 0 & 194 & 2 & 0.2 & $\begin{array}{c}0.32333 \\
3 \\
\end{array}$ \\
\hline 93 & 870 & 700 & 1570 & 676 & 70 & 0 & 746 & 4 & 0.430573 & $\begin{array}{c}0.47515 \\
9 \\
\end{array}$ \\
\hline 16 & 120 & 200 & 320 & 165 & 0 & 0 & 165 & 1 & 0.515625 & $\begin{array}{c}0.51562 \\
5 \\
\end{array}$ \\
\hline 113 & 660 & 400 & 1060 & 720 & 64 & 0 & 784 & 3 & 0.679245 & $\begin{array}{c}0.73962 \\
3 \\
\end{array}$ \\
\hline 4 & 130 & 0 & 130 & 45 & 52.5 & 6.5 & 104 & 1 & 0.346154 & 0.8 \\
\hline
\end{tabular}

